\title{
Political trust of the Dayak Paser indigenous law community regarding the capital city relocation policy
}

\section{Kepercayaan politik masyarakat hukum adat Dayak Paser terkait kebijakan relokasi ibukota negara}

\author{
Tengku Imam Syarifuddin*, Dian Eka Rahmawati, \& David Efendi \\ Master of Government Affairs and Administration, Universitas Muhammadiyah Yogyakarta \\ Address: Jalan Brawijaya, Tamantirto, Bantul, Special Region of Yogyakarta 55183 \\ E-mail: tengku.imam.pasca18@mail.umy.ac.id*, dianekarahmawati93@gmail.com, \& \\ defendi83@gmail.com
}

Article History: Received 7 January 2020; Accepted 15 October 2020; Published Online 8 December 2020

\begin{abstract}
The country's capital will succeed if it works well as the national government center, a prosperous and livable city. As the country's multifunctional capital, Jakarta has undoubtedly caused many social, political, and economic problems that are difficult to overcome. This article aims to determine the political trust in the indigenous law community of Dayak Paser concerning the national capital relocation policy, using qualitative analysis consisting of a literature study approach with Nvivo 12 Plus application to analyze the data derived from internet websites. The author used government alignments, cultural norms, and economic change as the indicators in this study. The author also separates the community of Dayak Paser into the indigenous law community and the indigenous leaders. The result is that the members of the indigenous law communities prefer the sustainability of the cultural norms. The dominant indigenous figures prefer the government's alignments. If the government guarantees the standard order, then the indigenous law community's site and rights will not go extinct. Indigenous leaders and the members of the indigenous law community are equally subordinate to the economic factors. The conclusion that the government's alignment toward sustainability cultural norms affects the economic changes. The author also recommends that the country's capital design should use a metaphorical concept approach.
\end{abstract}

Keywords: political trust; relocation of the capital city; policy; indigenous law community

\section{Abstrak}

Ibu kota negara akan berhasil jika berfungsi dengan baik sebagai pusat pemerintahan nasional, kota yang makmur dan layak huni. Sebagai ibu kota multifungsi negara, Jakarta tidak diragukan lagi telah menimbulkan banyak masalah sosial, politik, dan ekonomi yang sulit diatasi. Penelitian ini bertujuan untuk mengetahui kepercayaan politik masyarakat hukum adat Dayak Paser terhadap kebijakan pemindahan ibu kota negara; dengan analisis kualitatif yaitu pendekatan studi literatur menggunakan aplikasi Nvivo 12 Plus sebagai alat untuk menganalisis data yang berasal dari situs internet. Penulis menggunakan keberpihakan pemerintah, norma budaya, dan perubahan ekonomi sebagai indikator dalam penelitian ini. Penulis juga memisahkan masyarakat Dayak Paser menjadi masyarakat hukum adat dan tokoh adat. Hasilnya adalah anggota masyarakat hukum adat lebih mengutamakan kelestarian norma budaya; sedangkan tokoh adat yang dominan lebih menyukai keberpihakan pemerintah. Jika pemerintah menjamin tatanan standar, maka situs dan hak masyarakat hukum adat tidak akan punah. Pemimpin adat dan anggota komunitas hukum adat samasama tunduk pada faktor ekonomi. Simpulannya adalah keberpihakan pemerintah terhadap norma budaya keberlanjutan mempengaruhi perubahan ekonomi. Penulis juga merekomendasikan agar desain ibu kota negara menggunakan pendekatan konsep metaforis.

Kata kunci: political trust; relokasi ibukota; kebijakan; masyarakat adat; hukum adat

\section{Introduction}

The nation's capital is one of the essential features in the political geography of a country (Nwafor 1980). Seeing Jakarta today as the state capital is multifunctional, although it has caused many social, political, and economic problems that are difficult to overcome (Labolo et al. 2018). Data obtained from the Badan Pusat Statistik (BPS) province of Jakarta from 2010 to 2018 shows that the number 
of people in Jakarta increases. In 2010, Jakarta's population was 9.640 .406 people, which in 2014 rose to 10.075.310 (Badan Pusat Statistik 2015). The last data in 2018 showed that the population had reached 10.467.630 (Badan Pusat Statistik 2019). The McKinsey Global Institute (MGI) predicts that in 2030, the human population in Jakarta will reach 13 million people (Sodri \& Garniwa 2016). The expansion of urbanization will potentially aggravate problems such as the floods being increasingly uncontrollable, drought due to the water absorption decreasing, and the balance of water reserves disturbed by the function of the land changing so fast (de Azevedo Chagas et al. 2015, Remondi et al. 2016). Air pollution is also a problem in the capital of the country. Unhealthy air conditions have continued to increase from 2016-2019 based on the Air Pollution Index (API) data from the Jakarta Environment Agency. There were 93 days in 2016, 2017 (110), 2018 (187), and 2019 (183) that were unhealthy (Arumingtyas 2020). In addition to the increasing poverty, unemployment, waste disposal, poor transport management, widespread crime, and economic imbalance have also become problems in the nation's capital city (Labolo et al. 2018).

Every country has a capital, usually the largest city that serves as the government (Illman 2015). Ideally, the country's capital should ensure the right physical environment for the people who reside there than other cities (Hall 2002). The nation's capital will succeed if it works both as a national administrative center and a prosperous and livable city (Illman 2015). Jakarta does not facilitate this; it has been realized that the problems faced by the center of government and its current business are the result of the grandeur of the development in Jakarta (Labolo et al. 2018). Therefore, there must be a limitation of the capital city's role within the administrative boundary as the capital city's role will affect the current development of the future (Hall 2002, Takyi 2016). Its function is much more important than population agglomeration and complex infrastructures (Alwehab \& Juvara 2018). In addition to this limitation, this role will strengthen other cities' role to support the nation's capital in conveying other functions (Takyi 2016). The country's capital relocation is a more innovative and expensive tool for country building and national identification (Schatz 2003b). Sometimes the country decides to move its capital to another city or even be planned and constructed for the purpose (Illman 2015). Schatz (2003a) stated that there were issues when the national capital city relocation policy decided without financial, logistical, and political factors.

In the $20^{\text {th }}$ century, several new capitals were established in developing countries, such as Putrajaya (Malaysia) and Islamabad (Pakistan) (Kwon 2015). The reasons for moving the country's capital are very diverse (Illmann 2015). Some examples were built to develop national land, achieve balanced development, and facilitate political gains (Kwon 2015). The transfer depends on the needs of the country (Illmann 2015). Next, the author will try to describe the reasons why some countries relocate the country's capital. Turkey moved its capital to stand as a symbol of its new post-Ottoman state and its regime, Kazakhstan moved its capital to reinforce the Kazakh national identity, and Belize moved its capital to avoid the danger of hurricanes (Illmann 2015). South Korea moved its capital from Seoul to Sejong City on development distribution, reduced population density, and designing the new nation's capital model (Kwon 2015). India moved its capital that had previously been in Kolkata to New Delhi to a location free from British colonial influence and the government's affectivity and state development (Illman 2015). In addition, many other countries have decided to move their capital. Illman (2015) compiled a list of relevant countries and their reasons for moving the capital city (Table 1).

Schatz (2003a) argues there are several reasons behind the relocation of the nation's capital. First, the policy is to do with the "personal prestige" of the state leaders. In addition to authoritarian rulers' preference, it is understood to make decisions contrary to common sense against people's opposition and more prudent policymakers' advice. Second, the country's capital city is also often used as a commercial prospect. Third, the capital city's relocation claim of generating economic growth and improving administrative efficiency is reasonable; however, capital movements often have minimal success in these areas. Furthermore, it differs from Alwehab \& Juvara (2018) view concerning the relocation of the country's capital. They argue that there are only two reasons: to meet a political agenda and break down the nation's existing capital city's density. 
Table 1.

Reasons for relocating the national capital

\begin{tabular}{|c|c|c|c|c|}
\hline Country & Year & From & To & Reason \\
\hline India & 1911 & Kolkata & New Delhi & $\begin{array}{l}\text { Eschew the capital of the British anti- } \\
\text { bonding site, government's affectivity } \\
\text { and state development }\end{array}$ \\
\hline Russia & 1918 & St. Petersbrug & Moscow & $\begin{array}{l}\text { Security and ease of internal political } \\
\text { control. }\end{array}$ \\
\hline Turkey & 1923 & Istanbul & Ankara & $\begin{array}{l}\text { Historical and security; the logical } \\
\text { coherence of the Sultanate's } \\
\text { conservative militancy. }\end{array}$ \\
\hline Pakistan & 1959 & Karachi & Islamabad & $\begin{array}{l}\text { Karachi is considered unworthy, in } \\
\text { addition to strengthening the nation's } \\
\text { identity, and the political leader's policy. }\end{array}$ \\
\hline Brazil & 1960 & Rio de Janerio & Brasilia & $\begin{array}{l}\text { The economic development of rural } \\
\text { areas, strengthening the identity of the } \\
\text { nation, and the the previous capital is } \\
\text { considered unworthy }\end{array}$ \\
\hline Belize & 1970 & Belize City & Belmopan & $\begin{array}{l}\text { Avoiding storm catastrophes and } \\
\text { equitable development. }\end{array}$ \\
\hline Tanzania & 1974 & Dar es Salaam & Dodoma & $\begin{array}{l}\text { Equitable development and } \\
\text { strengthening the national identity. }\end{array}$ \\
\hline Malawi & 1975 & Zomba & Lilongwe & $\begin{array}{l}\text { Equitable development, political leader's } \\
\text { policy, and for the reason of unity }\end{array}$ \\
\hline $\begin{array}{l}\text { Cote } \\
\text { d'Ivoire }\end{array}$ & 1983 & Abidjan & Yamoussoukro & Political leader's policy \\
\hline Nigeria & 1991 & Lagos & Abuja & $\begin{array}{l}\text { National identity building, political } \\
\text { leader's policy, and Lagos is considered } \\
\text { unworthy of being the capital. }\end{array}$ \\
\hline Germany & 1991 & Bonn & Berlin & $\begin{array}{l}\text { Historical sequencing and country } \\
\text { integration. }\end{array}$ \\
\hline Kazakhstan & 1997 & Almaty & Astana & $\begin{array}{l}\text { Nation-building, State development, and } \\
\text { the policy leader's politics. }\end{array}$ \\
\hline Malaysia & 1999 & Kuala Lumpur & Putra Jaya & $\begin{array}{l}\text { Political policy of the leadership and part } \\
\text { of the identity building of the nation. }\end{array}$ \\
\hline Myanmar & 2006 & Yagon & Naypyidaw & $\begin{array}{l}\text { Reasons for security, following the } \\
\text { advice of forecasters, fears of foreign } \\
\text { invasion and political leader's policy. }\end{array}$ \\
\hline $\begin{array}{l}\text { South } \\
\text { Korea }\end{array}$ & 2012 & Seoul & Sejong City & $\begin{array}{l}\text { Equitable development, alienating the } \\
\text { capital from the country boundary. }\end{array}$ \\
\hline
\end{tabular}

Source: Illmann (2015)

In addition to the reasons behind moving the country's capital, the type of the nation's capital city itself should consider. There are seven types of capital cities: multifunction, global, political, former imperial, provincial, super, and the country's former capital (Alwehab \& Juvara 2018). Zimmermann (2010) argues that there are two types of national capital, specifically the country's capital, as the primary economic agglomeration and not a significant economic agglomeration. Alwehab \& Juvara (2018) also recommend that when relocating a country's capital, the new capital should become the administrative and political center while its old capital can develop into a business and investment center. Furthermore, capital planning and the associated design criteria have evolved dramatically over the past few decades; however, they are still somewhat slow (Alwehab \& Juvara 2018). Kwon (2015) argues there are two models used in national capital design based on the transit-oriented development model and the neighborhood development model. The Garden City model still considered viable even though it has been years since its commencement at the hands of Sir Ebenezer Howard in 
1898 (Alwehab \& Juvara 2018). The concept of metaphors can also adopt in designing the capital; It related to natural components in cities tends to evolve (Escobedo et al. 2018). Kutai Kartanegara and North Penajam Paser Regency of East Kalimantan Province was chosen as the relocation place for its capital. Ihsanuddin (2019) reported that President Joko Widodo announced the plan to relocate its capital to East Kalimantan and Central Kalimantan. Elections to make Eastern Kalimantan the state capital was based on infrastructure readiness and the potentially lower risk of geography-related natural disasters. In addition, East Kalimantan's precise coordinate point in the middle of Indonesia was one of the considerations. The nation's capital surround by two major cities in East Kalimantan, which are developing, specifically Balikpapan and Samarinda City (Ihsanuddin 2019).

It certainly raises the debate concerning the pros and cons of the community. Quite a number are doubtful about the relocation being realized, as the decision to relocate the country's capital is a challenging and difficult decision to act upon (Nwafor 1980). Nevertheless, it is impossible, as shown by significant states such as The United States, Brazil, and Australia, having once relocated their country (Potter 2017). The relocation of the nation's capital city will affect the development of the surrounding area, meaning that the equitable development in East Kalimantan will increase. Potter (2017) mentions that the transfer of the national capital from major cities outside of the big city area affects the areas outside the capital city.

The relocation of the nation's capital is also resulting in the rejection of the indigenous law community. As reported by Utama (2019), Dayak Paser, the indigenous law community around the relocation area of the national capital, has rejected the relocation plan. They dispute based on their experience with palm and timber companies. Customary settlements surrounded by Cultivation Rights or Hak Guna Usaha $(H G U)$ are the concern of the Dayak Paser customary law community coupled with the plan to relocate the nation's capital because regulations, sites, and customary rights are at risk of being made extinct and eroded due to developments (Utama 2019). It describes the doubt of the public in the government. The vital function of public trust in the state institutions must consider the state institutions' ability to manage the stability and economy. In addition to the functionality of maintaining the autonomy of the state's regulatory institutions, it is crucial to help ensure that the country is more manageable, stable, and prosperous. Such independence may disrupt several political leaders and groups (Cinar \& Ugur-Cinar 2018). Thontowi (2015) claims that the central government implements indigenous and tribal peoples' rights after receiving their consent and paying heed to their customary rights. Constitutional rights are related to the fulfillment of basic needs and fundamental freedoms. Legal rights are special or unique rights bound and held by the community based on origin (geographical), the equality of territory, and other traditional objects such as rights to customary land, rivers, forests, and community activities (Thontowi 2015).

Deda \& Mofu (2014) state that the indigenous law community's characteristics are human unity, living in a specific area in territorial cohesion, having a ruler or authority, having wealth due to tangible and intangible unity, and being a legal entity. Van Vollenhoven stated that long before independence in the archipelago, there were 19 customary jurisdictions (Sirait et al. 2001). The term 'indigenous law community' is often encountered when discussing natural resources (Sabardi 2014, Thontowi 2015). It is because the natural resources law study often discusses the meeting of interests and rules that are held by the indigenous law community when dealing with the state (Sabardi 2014). The rights of indigenous peoples are otohton, referring to a right that is a marker of a community's existence. Without being written into the country's law, it will remain an institution that lives on in the legal community as a custom. The development of the indigenous law community and its legal rights have been impoverished in many countries' constitutions, especially in the states where there has been colonialism (Kemnkumham 2014).

The state has secured the rights of the indigenous law community in the constitutional law through article 18B paragraph (2) and 28I (3) Constitution 1945, Law Number 5 of 1960 concerning agrarian points (Agrarian Law), Law Number 4 the year 2009 concerning mining, minerals, and coal and Law Number 7 the year 2004 on water resources and other rules. The indigenous law community's 
rights are also internationally recognized as defined by the International Labour Organization (ILO) convention results on Number 169 on the indigenous law community in independent countries valid from 5th September 1991 (Ismi 2012). The results of the convention stipulate that the state is obliged to uphold the cultural and spiritual values of the indigenous communities concerning the land that they occupy and/or use (Ismi 2012).

One of the rights owned by the indigenous law community is the right of ulayat, as stipulated in the Agrarian Law of article 3. The right of ulayat can be interpreted as the indigenous law community's right over its traditional territory (Thontowi 2015). From now on, article 18B paragraph (2) Constitution 1945 provides the requirements that must be fulfilled to protect the status of the indigenous law community and the rights of the ulayat. These requirements are first, for long as they are alive; secondly, following the development of society and third, following the ideals of the Republic of Indonesia's unitary State. These requirements stipulate the law. The right of ulayat is in addition to "Patuanan" or the lord of the land or Landlord (Deda \& Mofu 2014). Zakaria (2016) argues that there is a misinterpretation of customary rights, he stated that the right of ulayat is not merely an accepted right however to do with sovereignty, and he continued by stating that the right of ulayat divides into two, namely private and public.

The meeting of interests and rules held by the indigenous law community when dealing with the state often leads to a state victory (Sabardi 2014). The distrust of society in the government and political institutions poses a threat to the society as a whole and politics and democracy, clarifying the relationship with unbelief (Bertsou 2019). Haryanto (2019) view in their scientific speech, they stated that in order for there to be a government, there needs to be political trust amid the relationship between each of the actors, namely the central government and society. In addition, political belief is an essential indicator of political legitimacy; therefore, the level of political confidence that appears to decline in democratic countries has stimulated a growing research body into the cause and effect of political beliefs (Turper \& Aarts 2017). Levi \& Stoker (2000) argues that political trust is not only about satisfaction or dissatisfaction. It also concerns the sequencing of the perpetrators and the level of distrust in the government. A decline in political belief is often attributed to the long-term modernization and globalization process (Turper \& Aarts 2017). In addition, there is the perception that social problems are getting worse or remaining unresolved and that politicians are irresponsible citizens (Levi \& Stoker 2000).

Much literature states that the economic sector's role has a role in influencing political trust. In Canada, the government's expenditure rate, living standards, and economic growth influence political trust (Fortin \& Lemieux 2015). Aydin \& Cenker (2011) found that the Turkish community is satisfied with its economic welfare and that, as a result, it is 2.5 times more likely to express its satisfaction to the government. In addition, the extraction of resources that directly relates to the economic policy is one of the essential determinants of political confidence in democratic countries (Miller 2015).

In addition to the economic sector, the similarity of identity becomes a deciding basis for government trust. The research conducted by Mclaren (2016) in the European Community found that there is more confidence in the political system when there is a shared national identity. A more exclusive identity of the nation is thought to undermine the public belief in the government institutions that allow for the incorporation of immigrants into the political system (Ireland 2017). Several factors affect political trust in Japan, including community development, innovative policy enforcement, government alignment, and community welfare fulfillment (Lukner \& Sakaki 2017). Furthermore, Faulkner et al. (2015) summarized the survey trends over the past 50 years related to political confidence causes. The result is that economic change and uncertainty, declining social capital, cultural norm changes, increasing negativity, and lack of substance in the media, political leadership, institutional performance, and alignments all have differing levels of effect.

If people believe that the government is incompetent, dysfunctional, and untrustworthy, they are likely not to support politicians and governments. They are less likely to obey the law as a result 
(Faulkner et al. 2015). Political confidence affects policy-making, the apparatus's moral conduct, inter-community relations, and legitimacy (Cinar \& Ugur-Cinar 2018). A democratic regime's stability relies heavily on the citizens' support in political institutions (Cinar \& Ugur-Cinar 2018, Faulkner et al. 2015). Faulkner et al. (2015) also found that the country's rulers can manipulate political beliefs and beliefs in political and non-political institutions through the media.

Table 2.

Literature review on political trust

\begin{tabular}{lll}
\hline Government Alignment & \multicolumn{1}{c}{ Economic Change } & \multicolumn{1}{c}{ Cultural Norms } \\
\hline Lukner \& Sakaki (2017) & Fortin \& Lemieux (2015) & Faulkner et al (2015) \\
Cinar \& Ugur-Cinar (2018) & Aydin \& Cenker (2011) & Cinar \& Ugur-Cinar (2018) \\
Faulkner et al. (2015) & Miller (2015) \\
& Lukner \& Sakaki (2017) \\
& Faulkner et al. (2015) \\
\hline & Source: Data by author
\end{tabular}

Based on Table 2, the author formulated the research question asking how the political trust of the indigenous law community of Dayak Paser relates to the national capital city relocation policy. This article aims to determine the political trust of the indigenous law community and the national capital's relocation policy. In this article, the three indicators are used as a guideline in the analysis by the author.

\section{Research Method}

This research is a qualitative analysis conducted using a literature study approach. Qualitative research aims to understand and interpret the meaning of events and the interactions within human behavior in certain situations according to the researcher's perspective. It is carried out in natural settings and based on the phenomenological nature of understanding or prioritizing rewards (Gunawan 2013). Regarding a literature study conducted by qualitative researchers, its position can be seen as a resource that can answer questions such as: What is the purpose of the document written? What is his background? What can the document tell researchers? Under what conditions was the document written? Moreover, For whom is it written? (Nilamsari 2014).

Table 3.

Stages of the website analysis using NVivo Qualitative Data Analysis (QDA)

\begin{tabular}{ccccc}
\hline Tow level of strategy & \multicolumn{2}{c}{ Translated } & \multicolumn{2}{c}{ Tow level of tactic } \\
\hline Level 1 & Level 2 & Level 3 & Level 4 & Level 5 \\
Objectives & Analytical plan & Translation & Select Tools & $\begin{array}{c}\text { Constructed } \\
\text { tools }\end{array}$ \\
$\begin{array}{c}20 \text { news websites that share } \\
\text { information on the relationship } \\
\text { between the indigenous law } \\
\text { community and the government }\end{array}$ & $\begin{array}{c}\text { Ncapture } \\
\text { news website }\end{array}$ & $\begin{array}{c}\text { Input data into } \\
\text { NVivo 12 plus }\end{array}$ & $\begin{array}{c}\text { Crosstab, Text } \\
\text { Search and } \\
\text { Visualization }\end{array}$ & Combine \\
\hline
\end{tabular}

Source: Woolf \& Silver (2018)

This research used the NVivo 12 Puls software as the data analysis model. The software can analyze data originating from internet websites, and the feature used was Ncapture, which serves to duplicate the data on the website. This research has used several websites related to the relationship between the indigenous law community and the government about the national capital relocation policy. This study used tex research and crosstab as data analysis features, then used the Model Qualitative Data Analysis (QDA) (Woolf \& Silver 2018) to compare the news websites' data.

Table 3 explains that at Level 1, the author is adapting to the study targets and using the news websites' data analysis model. At this point, the author has listed 20 online news sites related to 
the customary law community's reaction to the state capital's relocation policy. Level 2 enters the analytic plan stage, where the author uses the Ncapture function to collect the data. Level 3 is the translation stage, where the author begins inputting data into the NVivo 12 Plus program and conducts coding activities. Level 4 enters the stage of Select Tools, where the author starts to use the resources available on NVivo 12 Plus, such as Crosstab Query, Text Search, and Visualization. Eventually, they enter Level 5, where the author has collected data further established by combining it with other applications. In this case, the author used Microsoft Excel to make the data presentation appear more proportional.

\section{Results and Discussion}

The government's relocation plan for the nation's capital is not inferior; however, the implementation must go through mature considerations such as finances, logistics, and political factors (Schatz 2003a). Furthermore, upon looking at Jakarta's situation and condition today as the country's capital, the author has argued that it is no longer feasible. The population density, air pollution, and various other problems have made Jakarta unable to accommodate the burden of being a multifunctional state capital. Furthermore, when the relocation of the country's capital was carried out, the function of the country's capital should be limited. Alwehab \& Juvara (2018) recommend that the country's new capital serve as administrative and political, while its old capital is used as the center of business and investment.

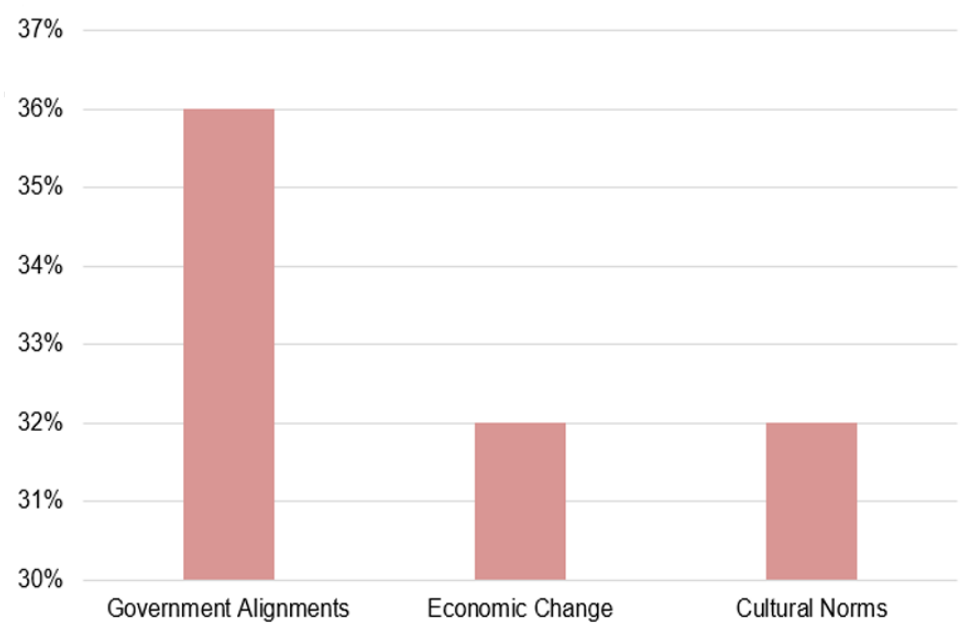

Figure 1.

Political trust of the indigenous people

In addition to the nation's capital functions, the country's capital design is also a concern. Some of the country's capital designs include the concept of transit-oriented development and model neighborhoods (Kwon 2015), in addition to Garden City (Alwehab \& Juvara 2018) and designing using the concept of metaphors (Escobedo et al. 2018). The author recommends using the metaphorbased concept design. It is based on the location of a country's capital surrounded by forests. In addition to keeping the forest ecosystem alive, it is also essential to ensure that indigenous law and living communities' sustainability is maintained. The author argues that the current design and function of the capital of the country will affect the political trust of the indigenous law community in the government.

Determine the political trust of the indigenous law community of Dayak Paser, used three factors: government alignment, economic change, and cultural norms. These factors are based on some of the previous articles' research results relating to political trust. It chose some of these causes as the factors of political trust in this study. In this research, the indigenous law community separates into the indigenous group members and the indigenous leaders. Members of the indigenous group are the indigenous community members who do not enter or serve in alliance or community gatherings on customary law. The indigenous leaders are the indigenous communities who are trusted to serve in 
alliances as a representative - this separation aim at providing objectivity. The author assumes that the indigenous peoples' opinions will not always be in line with the authoritative figures and often contradict each other.

Figure 1 explains how the indigenous communities' members declare their trust in the government based on three factors. They emphasize the guarantee of the continuity of their hereditary norm. The percentage of value produced based on cultural norms amounted to $36 \%$. The next factors on government alignment and economic change have the same value of $32 \%$. It suggests that economic change will be in line with the government's partiality to heeding the needs of the indigenous law community of Dayak Paser. The resulting percentage value shows no significant difference, at only $4 \%$, it signifies that the customary legal community members consider the three factors to defend their beliefs in a future capital relocation policy.

Choosing life's direction, including life paradigms, is the fundamental right of all people. Similarly, indigenous peoples have the freedom to maintain their existing values and norms, to develop them, or even to leave them behind. The author argues that the more significant percentage of the cultural norms are not detached from the orthodox community. Among the indigenous peoples who have lived as they do for generations, they feel that they are part of the environment. In other words, customary laws and societies make nature a part of them (Sirait et al. 2001). The values and norms in the community are formed based on their experience interacting with the environment. Sirait et al. (2001) argue that traditional law society's life is not separated from its natural resources relationship. It relates to the rights of indigenous peoples to manage their customary rights. Zakaria (2016) said that ulayat rights are sovereignty, referring to the fact that the exclusive customary legal community can manage its rights.

Figure 2 describes how the government's indigenous leaders' belief relates to the national capital relocation policy. Unlike the indigenous peoples who base their response on cultural norms, the indigenous leaders are more dominant regarding government alignment. The percentage of the value of the government's alignment from the indigenous leaders' perspective is $36 \%$. As the indigenous law community members, the exciting thing is that the indigenous leaders got the same value for cultural norms and economic change. The percentage of the two factors' value is $32 \%$, which is only $4 \%$ of the government alignment factor.

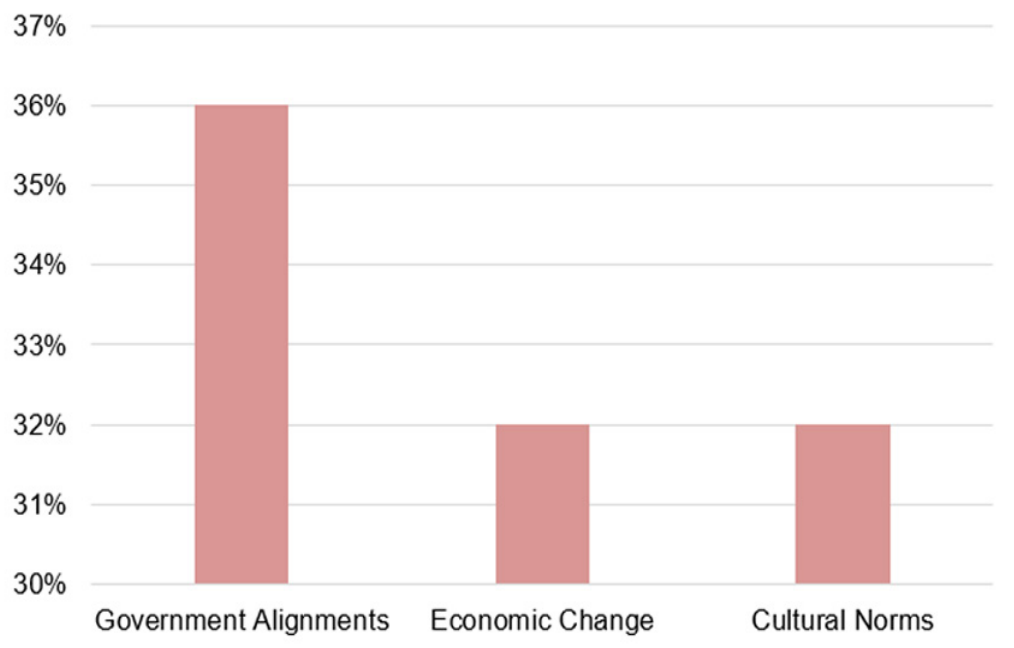

Figure 2.

Political trust of the indigenous leaders

Figure 2 shows the coding results of the political trust for the indigenous leaders. The political trust orientation of the indigenous leaders to government alignment is influenced by their experience of dealing with palm and timber companies' cultivation rights. Thontowi (2015) argues that the indigenous communities' interests clash with both the government and private companies. The indigenous community often suffers from defeat. The countries with power and interest often 
discriminate against the indigenous community. Sabukdin, as one of the customary heads of the indigenous law community of Dayak Paser, argues that migrants are already living on their land. The indigenous community does not feel a sense of well-being, especially when the capital city moved without any attention paid to them from the government. It will be resolved if the government guarantees their customary norms, the preservation of their sites, and the indigenous peoples' rights so they can avoid extinction (Utama 2019).

Figures 1 and 2 show that the economy is not a dominant factor desired by the Dayak Paser indigenous law community from the indigenous member perspectives and that of the indigenous leaders. Unlike other cases, such as Canada, Turkey, and other European countries, that have stated that the economic growth factor is a significant factor determining political trust (Aydin \& Cenker 2011, Fortin \& Lemieux 2015, Miller 2015). The author argues that the difference in interest, specifically concerning the social culture of the indigenous peoples of Paser and the community in some European countries, is one of the causes of this difference.

These results confirm that the government's alignment will determine the level of public confidence in the government. In Japan, the government's response to the tsunami catastrophe and the affected community was the determining factor in increasing political trust (Lukner \& Sakaki 2017). The government's alignment with the indigenous law community of Dayak Paser is limited to fulfilling their fundamental rights and legal rights. Legal rights are what the government is obliged to respect in terms of the culture and spiritual values of the indigenous and tribal peoples concerning the land they occupy and use (Ismi 2012). It should be of more concern going forward. Following the findings, the orthodox law community members emphasize the importance of the continuity of their cultural norms. Indigenous communities also have the right to the lands, territories, and resources they have historically owned, managed or used and the right to the lands, territories, and resources they traditionally owned. In addition, they also have the right to take part in decisions that can affect their rights (Thontowi 2015).

The reality is that in the process of fulfilling legal rights, it often collides with the interests of other actors, both government and corporate (Sabardi 2014, Thontowi 2015). Ideally, when there is a conflict, the government's position must ensure that their rights will be fulfilled. In the context of the relocation policy of the nation's capital, the government's partisanship must fulfill the Dayak Paser indigenous community's legal rights or the essential fulfillment of their customary rights. When the relocation is carried out, and the traditional territories traditionally owned by the Dayak Paser indigenous law community enter the development area, the government is obliged to compensate for losing their traditional territories.

To manage the traditional territories, the government will provide protection and guarantee to implement their customary rights. In accordance with the ILO Conventions, the indigenous law community has the right to carry out hunting, the management of forest products, and the exercising of their spiritual beliefs. In addition to fulfilling the rights of the Dayak Paser indigenous law community, the granting of a change of territory intended to be a counterweight to the state capital area to be built. It is so then the sustainability of the forests in the capital region of the country remains is preserved. The author recommends that the government adopt the capital design related to the concept of metaphors.

Furthermore, together with the provincial government of East Kalimantan, the government has put regulations in place governing the management of customary rights in the relocation area of the country's capital. Later on in the regulations, the Dayak Paser community will have the right to replace their territorial area if the development plan's customary area is included. The regulation must also maintain their obligation to their customary rights, including those of the Dayak Paser indigenous law community. It aims to ensure that the area is not sold to other parties in the future, so then the fulfillment of the indigenous community's rights is carried out, and the preservation of the natural ecosystem is maintained. 


\section{Conclusion}

The Dayak Paser indigenous law community supports the state capital's relocation policy to the government's traditional territory. Their experience of past policies results in doubt in the policies carried out by the government, which tests the political trust of the Dayak Paser indigenous law community concerning the national capital relocation. It examined several factors derived from the literature study, such as economic changes, cultural norms, and the government alignment with the indigenous law communities. The customary law communities divide into indigenous law communities and indigenous leaders to provide objectivity.

The result is that the indigenous and tribal peoples focus on the sustainability of their cultural norms. The indigenous law community makes nature a part of itself and makes nature its cultural norm. It relates to the rights of indigenous and tribal peoples to manage their customary rights. The management of ulayat by the indigenous law community is sovereignty. The indigenous leaders are predominantly concerned with the governmentss alignment. If the government guarantees the standard order, then the indigenous peoples' sites and rights will not go extinct, so the community>s customary law will not make them spectators in their own homes. Customary leaders and members of the customary law communities together engage with the economic factors as well. The author concludes that the government's alignment and the sustainability of the cultural norms will affect any economic changes.

In addition, the author recommends that the government adopts a design model with a metaphorical concept approach. This article considers this to be suitable, given the conditions around the capital city development area. Furthermore, together with the provincial government of East Kalimantan, the central government has made rules related to the use of customary land. It includes changing the area of the Dayak Paser indigenous law community, which included the relocation of the capital city. This regulation will also control the customary rights user's rights and obligations, namely the Dayak Paser indigenous law community. It is intended that the changing area of the Dayak Paser indigenous law community can be a counterweight to the state capital and that the Dayak Paser indigenous law community, as the holder of the management right, cannot sell it to other parties while acting as an actor participating in preserving the area.

\section{References}

Alwehab A \& Juvara M (2018) Planning and design attributes of preplanned postmodern capital cities: A comparative study. KnE Engineering 3 (4):208-224. https://doi.org/10.18502/keg. v3i4.2170.

Arumingtyas L (2020) Polusi udara, pembunuh senyap di Jabodetabek. [Accessed 21 August 2020]. https://www.mongabay.co.id/2020/04/25/polusi-udara-pembunuh-senyap-di-jabodetabek/.

Aydin A \& Cenker CI (2011) Public confidence in government: Empirical implications from a developing democracy. International Political Science Review 33 (2):230-250. https://doi. org/10.1177/0192512111417027.

Badan Pusat Statistik (2015) Jakarta dalam Angka 2015. Jakarta: BPS Provinsi DKI Jakarta.

Badan Pusat Statistik (2019) Provinsi DKI Jakarta dalam Angka 2019. Jakarta: BPS Provinsi DKI Jakarta.

Bertsou E (2019) Rethinking political distrust. European Political Science Review 11 (1):213-230. https://doi.org/10.1017/S1755773919000080.

Cinar K \& Ugur-Cinar M (2018) The effects of executive constraints on political trust. Democratization 25 (8):1519-1538. https://doi.org/10.1080/13510347.2018.1493050.

de Azevedo Chagas AT, da Costa MA, Martins APV, Resende LC, \& Kalapothakis E (2015) Illegal hunting and fishing in Brazil: A study based on data provided by environmental military police. Natureza \& Conservação 13 (2):183-189. https://doi.org/10.1016/j.ncon.2015.11.002. 
Deda A \& Mofu S (2014) Masyarakat hukum adat dan hak ulayat di Provinsi Papua Barat sebagai orang asli Papua ditinjau dari sisi adat dan budaya: Sebuah kajian etnografi kekinian. Jurnal Administrasi Publik 11 (2):11-22.

Escobedo FJ, Giannico V, Jim CY, Sanesi G, \& Lafortezza R (2018) Urban forests, ecosystem services, green infrastructure and nature-based solutions: Nexus or evolving metaphors? Urban Forestry \& Urban Greening 37 (2018):3-12. https://doi.org/10.1016/j.ufug.2018.02.011.

Faulkner N, Martin A, \& Peyton K (2015) Priming political trust: Evidence from an experiment. Australian Journal of Political Science 50 (1):164-173. https://doi.org/10.1080/10361146.2 014.979759 .

Fortin NM \& Lemieux T (2015) Changes in wage inequality in Canada: An interprovincial perspective. Revue Canadienne d'Économique 48 (2):682-713. https://doi.org/10.1111/caje.12140.

Gunawan I (2013) Metode Penelitian Kualitatif. Jakarta: Bumi Aksara.

Hall CM (2002) Tourism in capital cities. An International Interdisciplinary Journal 50 (3):235-248.

Haryanto (2019) Political Trust dalam penyelenggaraan pemerintahan daerah sebagai fondasi penguatan nation building. 5 September, Balai Senat Universitas Gajah Mada.

Ihsanuddin I (2019) Mengapa ibukota dipindahkan ke Kaltim? Ini penjelasan Jokowi. Kompas, 26 August. [Accessed 2 October 2019]. https://nasional.kompas.com/read/2019/08/26/ 14055421/mengapa-ibu-kota-negara-dipindah-ke-kaltim-ini-penjelasan-jokowi.

Illmann E (2015) Reasons for relocating capital cities and their implications. Thesis, Charles University, Prague.

Ireland PR (2017) Immigration and perceptions of national political systems in Europe. Perspectives on Politics 15 (4):1186-1188. https://doi.org/10.1017/S1537592717002638.

Ismi H (2012) Pengakuan dan perlindungan hukum hak masyarakat adat atas tanah ulayat dalam upaya pembaharuan hukum nasional. Jurnal Ilmu Hukum Riau 3 (1):1-22.

Kemenkumham (2014) Laporan akhir tim pengkajian konstitusi tentang perlindungan hukum terhadap masyarakat hukum adat. Pusat Penelitian dan Pengembangan Sistem Hukum Nasional (Vol. 3). https://bphn.go.id/data/documents/lap.akhir_pengkajian_konstitusi_perlindungan_ masyarakat_adat.pdf.

Kwon Y (2015) Sejong Si (City): Are TOD and TND models effective in planning Korea's new capital? Cities 42 (2015):242-257. https://doi.org/10.1016/j.cities.2014.10.010.

Labolo M, Averus A, \& Udin MM (2018) Determinant factor of central government relocation in Palangkaraya, Central Kalimantan Province. International Journal of Business and Management 2 (3):52-65. https://doi.org/10.26666/rmp.ijbm.2018.3.8.

Lukner K \& Sakaki A (2017) Japan's political trust deficit. Japan Forum 29 (1):1-18. https://doi.org/ 10.1080/09555803.2016.1227349.

Mclaren L (2016) Immigration, national identity and political trust in European democracies. Journal of Ethnic and Migration Studies 43 (3):379-399. https://doi.org/10.1080/136918 3X.2016.1197772.

Miller R (2015) Natural resource extraction and political trust. Resources Policy 45 (1):165-172. https://doi.org/10.1016/j.resourpol.2015.04.002.

Nilamsari N (2014) Memahami studi dokumen dalam penelitian kualitatif. Jurnal Wacana 14 (2):177-181.

Nwafor J (1980) The relocation of Nigeria's federal capital: A device for greater territorial integration and national unity. GeoJournal 4 (1980):359-360.

Potter A (2017) Locating the government: Capital cities and civil conflict. Research \& Politics 20 (1):1-7. https://doi.org/10.1177/2053168017734077.

Remondi F, Burlando P, \& Vollmer D (2016) Exploring the hydrological impact of increasing urbanisation on a tropical river catchment of the metropolitan Jakarta, Indonesia. Sustainable Cities and Society 20 (1):210-221. https://doi.org/10.1016/j.scs.2015.10.001. 
Sabardi L (2014) Konstruksi makna yuridis masyarakat hukum adat dalam Pasal 18B UUD RI tahun 1945 untuk identifikasi adanya masyarakat hukum adat. Jurnal Hukum \& Pembangunan 44 (2):170. https://doi.org/10.21143/jhp.vol44.no2.19.

Schatz E (2003a) What capital cities say about state and nation building. Nationalism and Ethnic Politics 9 (4):111-140. https://doi.org/10.1080/13537110390444140.

Schatz E (2003b) When capital cities move: The political geography of nation and state building. Working Paper of the Helen Kellogg Institute for International Studies 303, February 1.

Sirait M, Fay C, \& Kusworo A (2001) Bagaimana hak-hak masyarakat adat dalam mengelola sumber daya alam diatur? Southeast Asia Policy Research Working Paper 1 (24):1-35.

Sodri A \& Garniwa I (2016) The effect of urbanization on road energy consumption and CO2 emissions in emerging megacity of Jakarta, Indonesia. Social an Behavioral Sciences 227 (1):728-737. https://doi.org/10.1016/j.sbspro.2016.06.139.

Levi M \& Stoker L (2000) Political trust and trustworthiness. Annual Review of Political Science 3 (1):475-507. https://doi.org/10.1146/annurev.polisci.3.1.475.

Takyi SA (2016) Comparative study of capital city elements: The case of Ghana and Nigeria. African Geographical Review 35 (2):168-191. https://doi.org/10.1080/19376812.2015.1134335.

Thontowi J (2015) Pengaturan masyarakat hukum adat dan implementasi perlindungan hak-hak tradisionalnya. Pandecta: Research Law Journal 10 (1):1-13. https://doi.org/10.15294/ pandecta.v10i1.4190.

Turper S \& Aarts K (2017) Political trust and sophistication: Taking measurement seriously. Social Indicators Research 130 (1):415-434. https://doi.org/10.1007/s11205-015-1182-4.

Utama A (2019) Ibu kota baru Indonesia, Warga Dayak Paser khawatir 'makin tersingkir' dari wilayah adat, 'tidak mau tambah melarat.' BBC News, 6 September. [Accessed 2 October 2019]. https://www.bbc.com/indonesia/indonesia-49591240.

Woolf NH \& Silver C (2018) Qualitative Analysis Using Nvivo, The Five Level QDA Method. New York \& London: Routledge.

Zakaria RY (2016) Strategi pengakuan dan perlindungan hak-hak masyarakat (Hukum) adat: Sebuah pendekatan sosio-antropologis. BHUMI: Jurnal Agraria dan Pertanahan 2 (2):133. https:// doi.org/10.31292/jb.v2i2.66.

Zimmermann H (2010) Do different types of capital cities make a difference for economic dynamism? Environment and Planning C Government and Policy 28 (5):761-767. https://doi.org/ 10.1068/c286com. 